
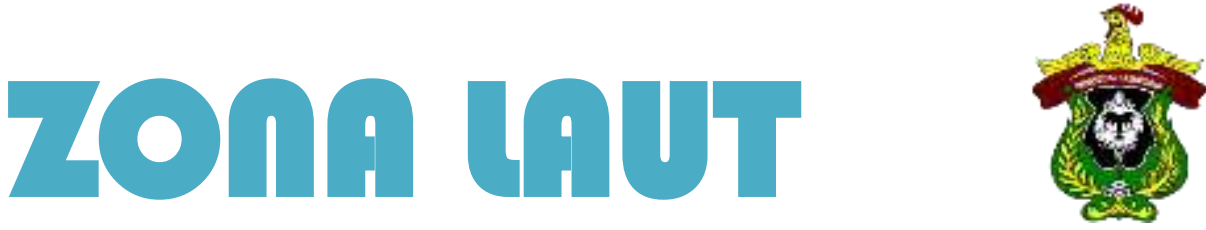

JURNAL INOVASI SAINS DAN TEKNOLOGI KELAUTAN

\title{
ANALISA PENGARUH JUMLAH MUATAN TERHADAP BEBAN SLOSHING TANGKI PADA KAPAL TANKER DENGAN METODE NUMERIK
}

\author{
*Amar ma'ruf, Daeng Paroka dan Habibi Palippui \\ Departemen Teknik Kelautan Universitas Hasanuddin \\ *amarmaruf160@gmail.com
}

\begin{abstract}
Abstrak
Tangki merupakan wadah penyimpanan muatan dan menjadi bagian utama kapal pengangkut cairan dan gas agar muatan terjaga dan aman. Sebagai media penyimpanan, tangki akan selalu mendapatkan beban yang berasal dari dalam maupun beban yang berasal dari luar tangki. Sloshing merupakan salah satu beban yang berasal dari dalam, sloshing timbul akibat adanya gerakan kapal/tangki mengakibatkan gerak bebas fluida berosilasi menghantam dinding tangki. Tujuan penelitian ini adalah mencari pengaruh muatan terhadap gerakan dan beban sloshing pada tangki dengan variasi jumlah muat. Model tangki yang digunakan mengambil referensi kapal tanker general purpose yang mengangkut minyak mentah dalam kondisi dua dimensi persegi panjang (midship) dengan lebar 8,6 m dan tinggi $8 \mathrm{~m}$ dua sisi kiri dan kanan. Variasi yang digunakan adalah volume muat 10\% (ketinggian 0,8 m), volume 30\% (ketinggian 2,4 m), volume $50 \%$ (ketinggian $4 \mathrm{~m}$ ), variasi 70\% (ketinggian 5,6 m) dan variasi 90\% (ketinggian 7,8 m). Simulasi dilaksanakan dengan metode numerik yaitu Computational Fluid Dynamic (CFD) menggunakan software Ansys Fluent. Gerakang tangki didasarkan dari gerakan kapal yang dalam hal ini dibatasi pada gerak heaving dan rolling, dari hasil simulasi disimpulkan bahwa efek sloshing terbesar terjadi pada variasi volume muat $10 \%$ frekuensi 2,145 , sedangkan tekanan terbesar terjadi pada titik sudut kiri bawah tangki dengan tekanan 443,29 Kpa.
\end{abstract}

Kata Kunci: Fluent, Heaving, Rolling ,Sloshing,Tangki.

\begin{abstract}
Tank is a cargo storage container and is the main part of ships carrying liquids and gases so that the cargo is maintained and safe. As a storage medium, the tank will always get loads that come from inside as well as loads that come from outside the tank, sloshing is one of the loads that come from inside. Sloshing occurs due to the movement of the vessel/tank resulting in free motion of oscillating fluid hitting the tank wall. The purpose of this study was to find the effect of the load on the movement and sloshing load on the tank with variations in the amount of load. The tank model used is a reference to a general purpose tanker transporting crude oil in two-dimensional rectangular conditions (midship) with a width of $8,6 \mathrm{~m}$ and $a$ height of $8 \mathrm{~m}$ on both the left and right sides. The variations used are 10\% load volume (0,8 $\mathrm{m} \mathrm{high),30 \%}$ volume (2,4 $\mathrm{m}$ high), 50\% volume (4 $\mathrm{m}$ high), 70\% variation (5,6 $\mathrm{m}$ high) and $90 \%$ variation (high 7,8 $\mathrm{m}$ ). The simulation was carried out with a numerical method, namely Computational Fluid Dynamic (CFD) using Ansys Fluent software. The back of the tank is based on the movement of the ship which in this case is limited to heaving and rolling motion, from the simulation results it is concluded that the biggest sloshing effect occurs at the load volume variation of $10 \%$, the frequency is 2.145, while the greatest pressure occurs at the lower left corner of the tank with a pressure of 443,29 Kpa.
\end{abstract}

Keyword: Fluent, Heaving, Rolling, Sloshing and Tank.

\section{PENDAHULAN}

Tangki merupakan wadah penyimpanan muatan dan menjadi bagian utama kapal pengangkut cairan dan gas. Sebagai media penyimpanan muatan [1], tangki akan selalu mendapatkan beban baik dari dalam dari luar, sloshing merupakan salah satu contoh beban yang berasal dari dalam [2], [3]. Oleh karena itu perlu adanya simulasi sloshing dan analisa struktur pada tangki akibat gaya yang ditimbulkan oleh beban tersebut [4]. 
Sloshing merupakan efek dari gerak bebas fluida dalam tangki dengan gerakan menghantam dinding tangki [5][[6]. Pada penelitian ini mengambil referensi tangki berbentuk kotak pada kapal tanker general purpose yang mengangkut minyak mentah, parameter yang divariasikan adalah volume muat $10 \%, 30 \% 50 \%$, 70\% dan 90\%, dengan gerakan kapal rolling dan heaving[7][8].

Penelitian ini akan melakukan analisa karakteristik gerakan sloshing dan arah gerakan sloshing muatan yang berhubungan dengan gerakan kapal. Dengan adanya analisa tersebut dapat diketahui distribusi nilai tekanan dan bagian dinding tangki yang mengalami potensi kerusakan tersebesar saat terjadinya rolling dan heaving [9].

\section{METODELOGI}

Pada penelitian ini analisa mengambil variasi volume muatan kapasias dari tangki kapal tanker berbentuk prismatik segiempat dengan muatan minyak mentah. Penelitian ini menganalisa karakteristik gerakan sloshing yang ditimbulkan oleh gerakan kapal. Analisa seakepper disimulasikan dengan software maxsurf motion, adapun data yang diperlukan adalah model kapal, kecepatan kapal, [10] arah datang gelombang, kondisi lingkungan yang meliputi tinggi gelombang, periode dan ecounter frekuensi. Dari hasil simulasi menghasilkan grafik gerak kapal terhdap waktu yang membentuk persamaan gerakan kapal yaitu heaving dan rolling, dari nilai amplitudo dan frekuensinya maka gerakan tangki dapat dimasukkan pada ansys fluent dengan menggunakan user define function [11]. Dengan menentukan geometri tangki dan properti fluida pada Ansys fluent serta menentukan gerakan tangkinya, maka simulasi sloshing dapat dijalankan yang hasilnya merupakan gerakan osilasi muatan dalam tangki serta tekanan yang dihasilkan dalam bentuk animasi serta grafik [12].

\subsection{Lokasi dan Waktu Penelitian}

Penelitian ini dilakukan pada bulan November 2020-Selesai, di ruang Laboratorium Dinamika Bangunan Apung, Departemen Teknik Kelautan Fakultas Teknik Universitas Hasanuddin.

\subsection{Teknik Pengumpulan Data}

Sumber data dalam penelitian ini, untuk data ukuran utama kapal dan tangki diperoleh hasil penelitian "Studi Pengaruh Peletaan Sekat Memanjang Pada Tangki Kapal terhadap Stabilitas Kapal Tanker” Penelitian Mahmud R pada tahun 2018. Data yang diperoleh berupa ukuran utama kapal dan linsplan kapal dalam file maxsurf. Data kapal yang digunakan, Length Over All (LOA) adalah 108 m, Length Between Perpencidular (LBP) adalah 101,85 m, Breadth (B) adalah 19,2 m, Depth (H) adalah 9,3 m, Draught (T) adalah $6 \mathrm{~m}$ dan Displacment adalah 9863 ton.

Untuk data gelombang diperoleh dari website ECMWF yang diambil dari alur pelayaran Bali-Lombok. Adapun data gelombang signifikan tahunan yang diperoleh nilai maksimum pada tahun 2012 dengan tinggi $2,86 \mathrm{~m}$ dan periode $8,85 \mathrm{~s}$.

\subsection{Metode Analisa Data}

Pada tahapan ini data linesplan dalam bentuk file maxsurf dianalisis pada maxurf motion untuk mendapatkan data seakepper. Amplitudo (Zo ) yang dihasilkan oleh software seakeeper dalam heaving kapal tersebut adalah $1,33 \mathrm{~m}$, Sehingga persamaan gerakan heaving kapal tersebut adalah :

$$
\begin{gathered}
Z=- \text { Zo cos. }(\omega \mathrm{e} . \mathrm{t}) \\
Z=-1,33 \cdot \cos .(0,715 . \mathrm{t})
\end{gathered}
$$

Sedangkan amplitudo yang dihasilkan oleh software seakeeper dalam gerakan pitching kapal tanker tersebut adalah 0,0944 radian. Sehingga persamaan gerakan rolling kapal tersebut adalah :

$$
\begin{gathered}
\theta=\theta \text { o.cos. }(\omega \mathrm{e} . \mathrm{t}) \\
\theta=0,0944 \cdot \cos (0,715 . \mathrm{t})
\end{gathered}
$$


Hasil gerakan kapal tersebut juga merupakan gerakan tangki yang ada didalam Kapal tanker. Hasil gerakan tersebut kemudian dikonversi kedalam satuan kecepatan tangensial dan kecepatan sudut kedalam bahasa C++ untuk mendifinisikan gerakan tangki dan dicompile kedalam user define program software Ansys Fluent.

\subsection{Penggunaan User Define Function (UDF)}

User defined function (UDF) merupakan fitur yang diberikan oleh Ansys Fluent yang bertujuan untuk menganalisa gerakan fluida, chemical reaction, property fluida dan sebagainya. Dalam tugas akhir ini menggunakan User defined function untuk mendeskripsian gerakan tangki yang telah diperoleh dari hasil simulasi dari seakeeper.

User defined yang dibutuhkan dalam tugas akhir ini yaitu penentuan gerakan couple rolling dan heaving. Sedangkan dalam mendifinisikan gerakan tangki, dibutuhkan kecepatan gerakan sehingga persamaan gerakan rolling dan heaving yang telah didapat diturunkan menjadi kecepatan gerakan yang dialami tangki di dalam kapal.

\section{HASIL DAN PEMBAHASAN}

Hasil dan pembahasan pada penelitian ini terkait dari hsil yang didapatkan dari simulasi sloshing muatan pada Ansys Fluent dengan berbagai variasi jumlah volume muat sesuai pada kondisi batas yang telah ditentukan.

\subsection{Node Pressure pada Tangki}

Node pressure merupakan titik untuk menentukan titik acuan pengambilan data tekanan yang dihasilkan pada dinding tangki, oleh karena itu ditentukan node pressure pada dinding sisi kiri (sisi A), sisi tengah, (sisi B) dan sisi kanan (sisi C) secara merata ke bawah sebagai titik acuan bahan perbandingan distribusi tekanan vertikal. Setiap titik node pressure mewakili titik permukaan pada variasi volume muat fluida seperti pada gambar berikut.

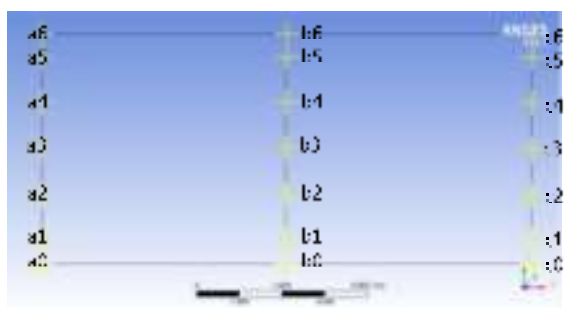

Gambar 1. Penentuan node pressure

\subsection{Simulasi Sloshing Frekuensi}

Dalam penelitian ini, metode simulasi yang digunakan menggunakan model Multiphase-Volume of Fluid, Viscous-Standar K Epsilon Standarr Wall Function. Gerakang tangki ditentukan dengan menggunakan Dynamic mesh serta volume fluida ditentukan melalui Cell Registers dan Instalation dengan menentukan daerah yang didefinikan sebagai udara dan fuel oil liquid.

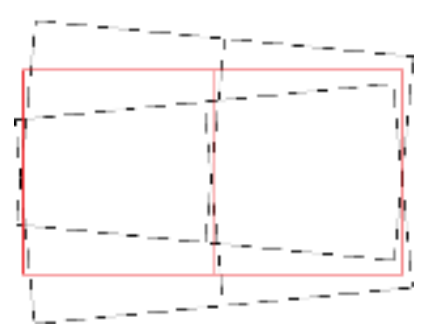

Gambar 2. Gerakan Tangki dengan Dynamic Mesh

Gerakan tangki dimulai dengan gerakan ke bawah (nilai heaving negatif) yang dikombinasikan dengan miring ke kiri berlawanan arah jarum jam (rolling positif), setelah mencapai heaving minimum dan rolling maksimum kemudian tangki kembali bergerakan ke atas (nilai heaving positif) dan kombinasi miring ke kanan (rolling copyright is published under Lisensi Creative Commons Atribusi 4.0 Internasional. 
negatif). Dari proses komputasi menggunakan software ansys fluent dengan waktu 100 simulasi detik Hasil animasi volume rendering gerakan sloshing muatan serta distribusi tekanan yang dihasilkan terhadap waktu pada variasi volume muat dapat dilihat pada Tabel 1.

Tabel 1. Rendering gerakan dan distribusi tekanan

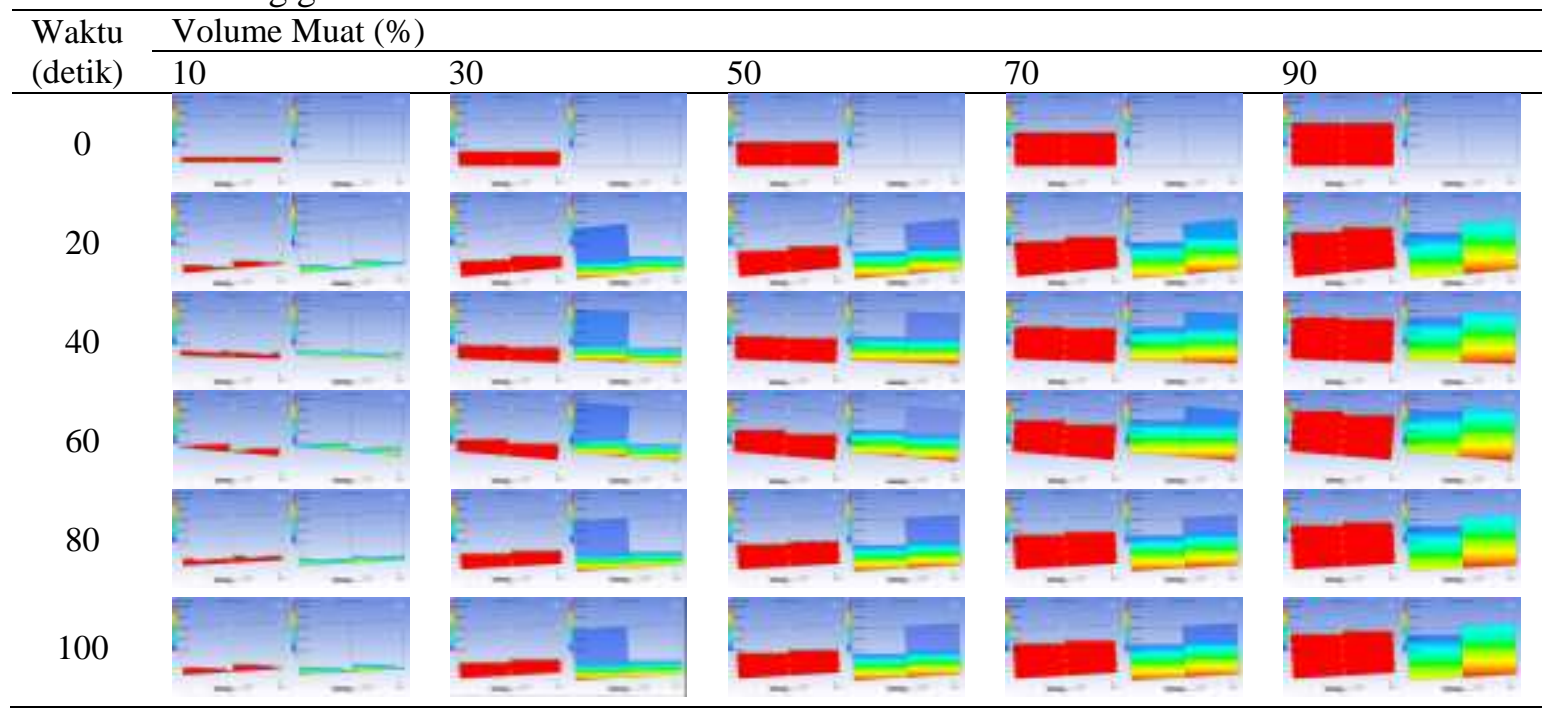

Simulasi sloshing dengan variasi volume muat berbeda-beda menghasilkan gerakan osilasi muatan dengan karakteristik yang berbeda-beda, slohing terlihat jelas pada variasi volume muat $10 \%$ sedangkan pada variasi volume muat lain kurang menghasilkan efel sloshing atau cenderung stabil. Dari hasil simulasi sloshing dari beberapa variasi volume muat, dengan mengambil nilai tekanan maksimum pada setiap node pressure pada dinding tangki, hubungan antara tekanan maksimum dengan volume muat datanya disajikan dalam bentuk grafik pada Gambar 3.
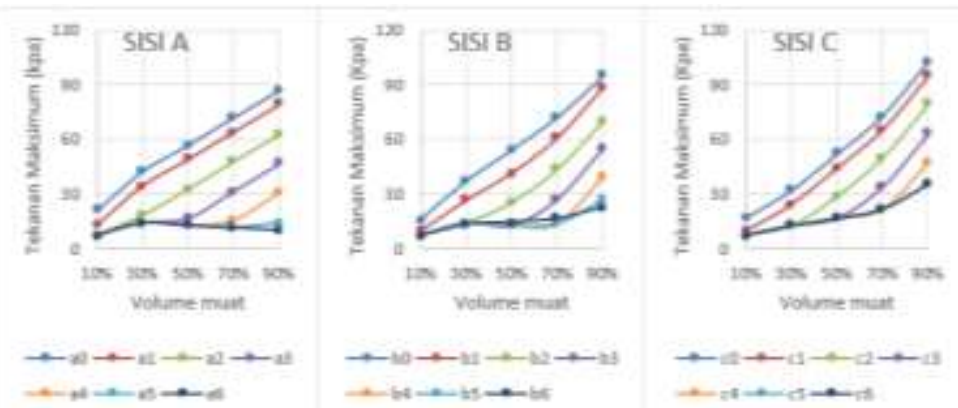

Gambar 3. Grafik tekanan maksimum terhadap volume muat

Secara umum tekanan yang dihasilkan dari simulasi meningkat seiring dengan bertambah besarnya variasi volume muatan, tekanan terbesar terjadi pada titik a0 yang terletak pada bagian dasar tangki, dan tekanan yang berada di atas permukaan muatan cenderung memiliki terkanan yang sama merata karena tidak mengalami tekanan hidrostatis.

Pada sisi A Terkhusus pada variasi volume muat 30\%, titiik node pressure a3, a4, a5 dan a6 (di atas permukaan muatan) memiliki nilai tekanan yang sedikit melonjak dan setelahnya pada variasi volume muat 50\%, 70\% dan $90 \%$ nilai tekanan yang dihasilkan kembali menurun.

Pada sisi B Terkhusus pada variasi volume muat 30\%, node pressure b3, b4, b5 dan b6 (di atas permukaan muatan) nilai tekanan yang dihasilkan sedikit melonjak kemudian setelahnya (volume muat 50\% dan 70\%) nilai tekanan mendatar dan kembali melonjak pada variasi volume muat $90 \%$, terkhusus pada titik node pressure b6 yang terletak pada bagian tutup tangki memiliki nilai tekanan lebih besar dibandingkan tekanan pada titik b4 dan b5 dibawahnya pada variasi volume muat 50\% dan $70 \%$.

Pada sisi $\mathrm{C}$ tekanan terbesar yang dihasilkan terjadi pada titik $\mathrm{c} 0$ yang terletak pada dasar tangki, dan tidak ada lonjakan nilai tekanan pada variasi $30 \%$ berbeda dengan dinding tangki sebelumnya yaitu sisi A dan B. Pada sisi $\mathrm{C}$ nilai tekanan selalu berbanding lurus dengan volume muat. 
Dari ketiga grafik dapat diketahui bahwa semakin tinggi jarak antara titik node pressure dari dasar tangki maka tekanan yang hasilkan juga akan semakin rendah dan sebaliknya semakin ke bawah node presure maka nilai tekanan yang dihasilan juga akan semakin besar. Pada ketinggian $0 \mathrm{~m}$ pada dasar tangki menghasilkan nilai tekanan terbesar.

\subsection{Simulasi Sloshing Frekuensi 1,43}

Terkait dari tujuan penelitian untuk mencari gerakan osilasi slohing muatan akibat adanya permukaan bebas fluida di dalam tangki disertai gerakan kapal, dengan variasi parameter volume muat. Simulasi pada encounter frekuensi $(0.715)$ luaran yang dihasilkan masih kurang memberikan efek gerakan osilasi muatan pada beberapa volume muat dan hanya terlihat jelas pada variasi volume muat $10 \%$, oleh karena itu maka jumlah simulasi ditambahkan dengan meningkatkan nilai dari frekuensinya menjadi sebesar 1,43 (dua kali lipat dari encounter frekuensi) dengan harapan dari simulasi yang diluarkan dapat memberikan hasil osilasi gerakan muatan pada variasi volume muat $50 \%$.

Dari proses komputasi menggunakan software ansys fluent dengan waktu 100 simulasi detik, hasil animasi volume rendering gerakan sloshing muatan serta distribusi tekanan yang dihasilkan terhadap waktu pada variasi volume muat frekuensi 1,43 dapat dilihat pada Tabel 2.

Tabel 2. Rendering gerakan dan distribusi tekanan frekuensi 1,43

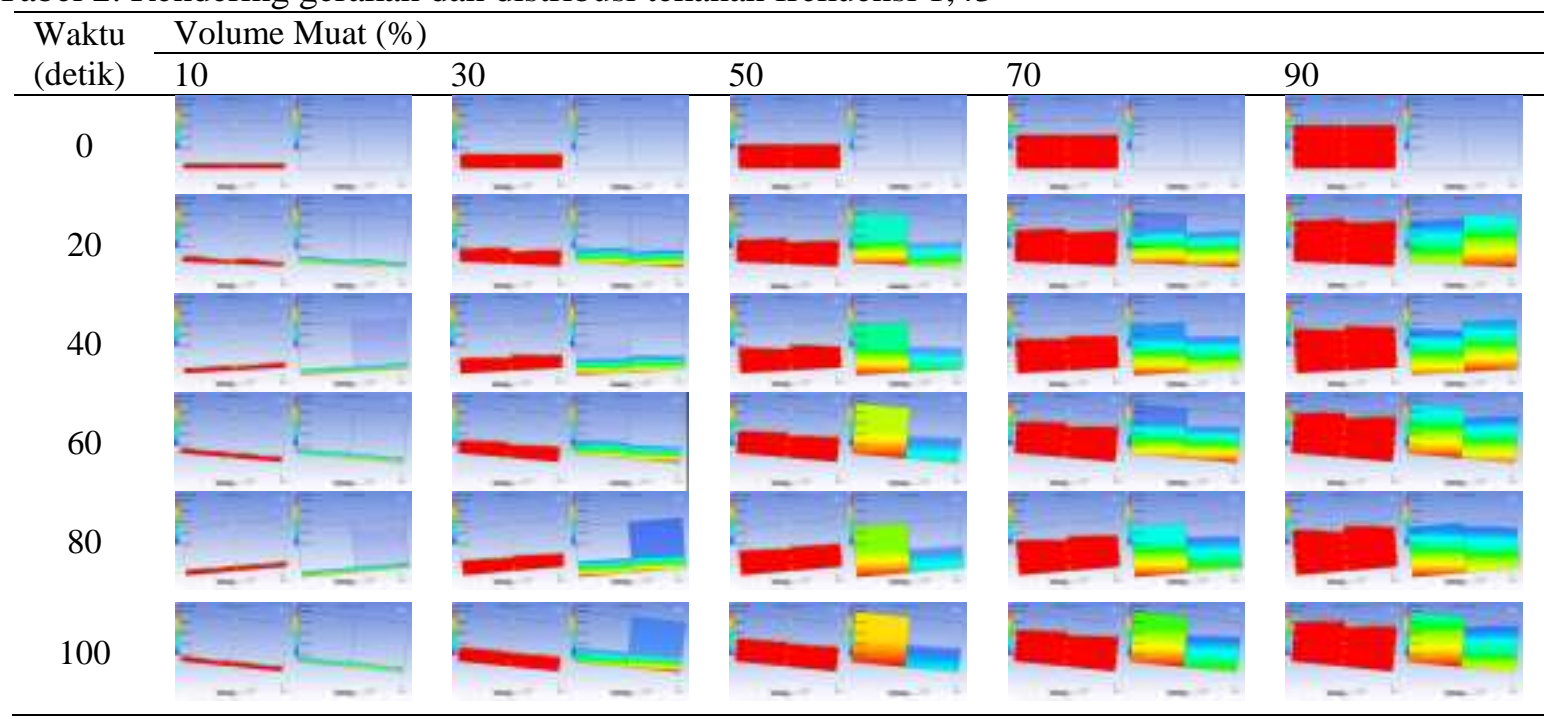

Gerakan osilasi muatan atau slohing terlihat jelas pada variasi volume muat $10 \%$, volume $30 \%$ dan volume $90 \%$, kurang terlihat pada variasi volume muat 50\% dan hampir tidak terlihat pada variasi volume muat $70 \%$. Dari hasil simulasi sloshing dari beberapa variasi volume muat, dengan mengambil nilai tekanan maksimum yang dihasilkan pada setiap node pressure yang terletak pada dinding tangki, hubungan antara tekanan maksimum dengan volume muat datanya disajikan dalam bentuk grafik dan dapat dilihat pada Gambar 4 .

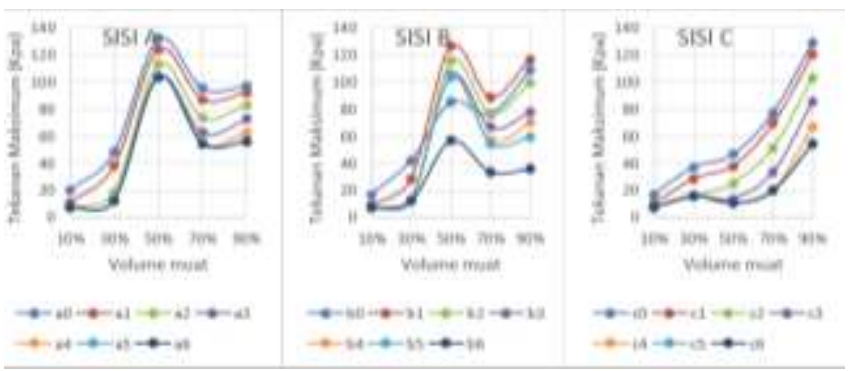

Gambar 4. Grafik tekanan maksimum tehadap volume muat frekuensi 1,43

Secara umum nilai tekanan meningkat seiring dengan bertambah besarnya volume muatan di dalam tangki. Pada sisi A tekanan terbesar yang dihasilkan terjadi pada titik a0 (ketinggian $0 \mathrm{~m}$ ) yang terletak pada dasar tangki, namun pada variasi volume muat 50\% memiliki karakteristik nilai tekanan yang melonjak jauh lebih besar dibandingkan dengan variasi volume muat $70 \%$ dan volume muat $90 \%$. Besarnya nilai tekanan pada variasi volume muat 50\% dikarenakan adanya lonjakan ekstrim sepanjang durasi berjalannya waktu simulasi. copyright is published under Lisensi Creative Commons Atribusi 4.0 Internasional. 
Secara berturut turut nilai tekanan terbesar terjadi pada variasi volume muat $50 \%$, disusul variasi volume muat $90 \%$, volume muat $70 \%$, volume muat $30 \%$ dan terahir volume muat $10 \%$.

Pada sisi B variasi volume muat 50\% memiliki nilai tekanan yang jauh melonjak lebih besar dibandingkan dengan variasi volume muat $70 \%$ dan volume muat $90 \%$. Terkhusus pada node pressure b0 (ketinggian $0 \mathrm{~m}$ ) terletak di dasar tangki pada variasi volume muat 50\% kurang mengalami pengingkatan jauh dibandingkan node pressure lain yang mengalami lonjakan tekanan yang signifikan. Secara berturut turut tekanan terbesar terjadi pada variasi volume muat $50 \%$, disusul variasi volume muat $90 \%$, volume muat $70 \%$, volume muat $30 \%$ dan terakhir variasi volume muat $10 \%$.

Pada sisi $\mathrm{C}$ secara umum besar tekanan yang terjadi pada setiap node pressure meningkat seiring dengan bertambahnya volume variasi muat. Berbeda dengn sisi A dan B di sisi C tekanan pada volume $50 \%$ cendrung menurun/menonjol ke bawah.

Dari ketiga grafik di atas, nilai tekanan terbesar terjadi pada variasi volume muat 50\%, untuk dinding tangki sisi A dan B namum pada sisi C justru tekanan tidak meningkat secara signifikan.

\subsection{Simulasi Sloshing Frekuensi 2,145}

Dari proses komputasi menggunakan software ansys fluent dengan waktu 100 simulasi detik, hasil animasi volume rendering gerakan sloshing muatan serta distribusi tekanan yang dihasilkan terhadap waktu pada variasi volume muat frekuensi 2,145 dapat dilihat pada Tabel 3.

Tabel 3. Rendering gerakan dan distribusi tekanan frekuensi 2,145

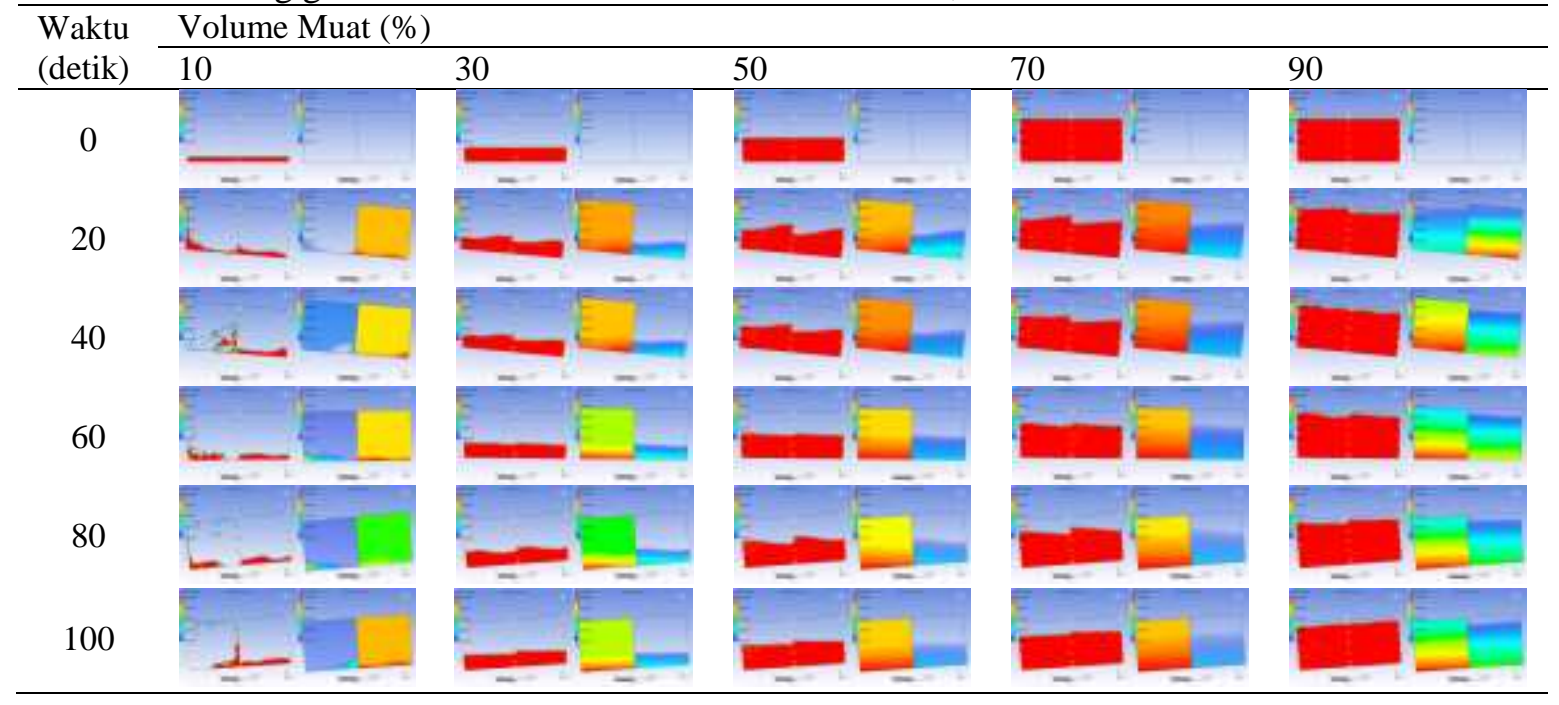

Simulasi sloshing dengan variasi volume muat berbeda-beda menghasilkan gerakan osilasi muatan dengan karakteristik yang berbeda-beda, slohing terlihat jelas pada hampir setiap variasi volume muat. Terkhusus pada variasi volume muat $10 \%$ memperlihatkan rambatan muatan sehingga merambat ke langit-langit tangki. Dari hasil simulasi sloshing dari beberapa variasi volume muat, dengan mengambil nilai tekanan maksimum pada setiap node pressure yang terletak pada dinding tangki, hubungan antara tekanan maksimum dengan volume muat datanya disajikan pada grafik dan dapat dilihat pada Gambar 5.
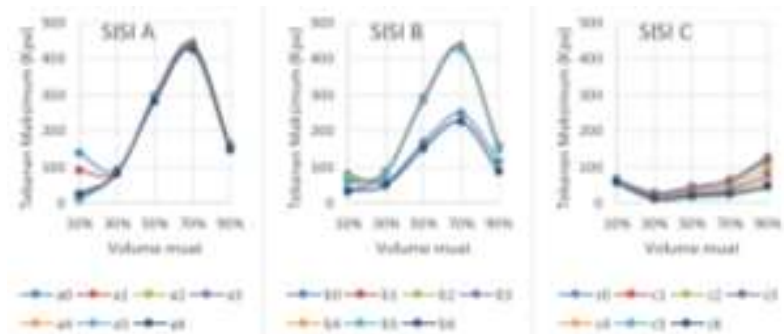

Gambar 5. Grafik tekanan maksimum tehadap volume muat frekuensi 2,145

Pada sisi A Tekanan pada setiap node pressure meningkat seiring dengan bertambahnya volume muat, namum pada variasi volume muat $90 \%$ justru lebih rendah dari variai volume muat $30 \%$. Pada variasi volume muat copyright is published under Lisensi Creative Commons Atribusi 4.0 Internasional. 
$10 \%$ nilai terkanan terlihat lebih terdistribusi berbeda dengan variasi volume muat yang lain nilai tekanan cenderung hampir sama merata pada setiap node pressure. Tekanan terbesar pada variasi volume muat $70 \%$, disusul variasi volume muat $50 \%$, volume muat $90 \%$, volume muat $10 \%$ dan terakhir volume muat $30 \%$.

Pada sisi B tekanan meningkat seiring dengan kedalaman tangki. Sementara variasi volume muat $10 \%$ nilai terkanan terlihat lebih sedikit terdistriusi, pada variasi volume muat yang nilai besar tekanan cenderung hampir sama merata pada setiap node pressure, terkecuali pada node pressure titik b0 yang berada pada dasar tangki, cenderung memiliki nilai tekanan yang hampir sama pada titik

Pada sisi $\mathrm{C}$ tekanan pada setiap node pressure meningkat seiring bertambahnya volume muat. Namum pada variasi $10 \%$ memiliki nilai tekanan yang lebih besar pada variasi $30 \%$, volume muat $50 \%$ dan volume muat.

Dari ketiga grafik di atas, nilai tekanan terbesar terjadi pada variasi volume muat $70 \%$, untuk dinding tangki sisi A dan B namum pada sisi C tekanan tidak meningkat secara signifikan dan terbesar pada variasi $10 \%$.

\section{KESIMPULAN}

Dalam penelitian ini, adapun kesimpulan yang dihasilkan dari simulasi Ansys Fluent disusun berdasarkan pada rumusan masalah yang telah dicari solusinya:

a. Pada encounter frekuensi 0,715 efek sloshing hanya terjadi pada variasi volume muat $10 \%$, untuk frekuensi 1,43 gerak osilasi terlihat jelas pada variasi volume muat $10 \%, 30 \%$, dan $90 \%$, kurang terlihat pada variasi $50 \%$ dan tidak terlihat pada variasi $70 \%$, untuk frekuensi 2,145 setiap variasi volume muat menunjukkan gerak osilasi yang jelas, terkhusus pada volume $10 \%$ memperlihatkan muatan merambat sampai ke bagian atas/tutup tangki, untuk variasi lain juga memperlihatkan gerak osilasi muatan.

b. Pada encounter frekuensi karena kurangnya efek osilasi muatan yang dihasilkan maka tekanan berbanding lurus dengan volume muat, untuk frekuensi 1,43 tekanan terbesar terjadi pada variasi volume muat 50\% dan untuk frekuensi 2,145 tekanan terbesar terjadi pada variasi volume muat $70 \%$.

\section{DAFTAR PUSTAKA}

[1] Anderson J.D, J. (1995). Computational Fluid Dynamics: The basics with applications. ISBN 0-07113210-4: McGraw-Hill.

[2] Bhattacharrya, R. (1978). Dynamics Of Marine Vehicles. New York: Wiley Publication.

[3] Djatmiko, E. B. (2012). Perilaku dan Operabilitas Bangunan Laut di Atas Gelombang Acak. Surabaya: ITS Press.

[4] International Chamber of Shipping. (2006). International Safety Guide for Oil Tankers and Terminals. London: Witherby \& CO.LTD.

[5] Mahmud, R. (2018). Studi Pengaruh Peletakan Sekat Memanjang Pada Tangki Kapal Terhadap Stabilitas Kapal Tanker. Gowa: Universitas Hasanuddin.

[6] Marton, G. (2007). Tanker Operation Fifth Edition. Mary Land England.

[7] Mikelis N and Journee. (1984). Experimental and Numerical Simulation of Sloshing Behaviour in Liquid Cargo Tanks and Its Effect on Ship Motion.

[8] Nuswantara, d. (2014). Regasification of LNG (Liquefied Natural Gas). Surabaya: Institut Teknologi Sepuluh Nopember (ITS).

[9] H. Palippui dan S. Ramadhan, "Analisa Kekuatan Struktur Barge Pada Proses Load Out Offshore Module (Top Side) dengan SPMT”, zonalaut, vol. 1, no. 1, hlm. 1-5, Mar 2020.

[10] Pratama, Y. A. (2017). Simulasi Sloshing Pada Tiga Tipe Tangki Kapal Akibat Gerakan Pitching Dan Heaving. Surabaya: Institut Teknologi Sepuluh Nopember.

[11] Sholeh, R. F. (2015). Transversal Sloshing Analysis for Independent Supporting Tank Type C LNG Carrier Due to Ships Swaying, Heaving, and Rolling Motion Using Computitational Fluid Dynamics Method. Surabaya: Institut Teknologi Sepuluh Nopember.

[12] Vinaya, e. a. (2013). Perancangan Sistem Kontrol Trajectory pada Kondisi Ganguan Arus Laut Non Uniform di Ketapang-Gilimanuk. Surabaya: Institut Teknologi Sepuluh Nopember.

[13] Yunus A, et al. (2006). Fluid Mechanics Fundamentals And Application. Americas, New York: McGraw-Hill. 